\title{
Climate change effect on sour cherry production in Central Hungary
}

\author{
Mézes, $\mathbf{Z}$. \\ University of Debrecen, Centre of Agricultural Sciences and Engineering, Faculty of Agricultural \\ and Food Sciences and Environmental Management, \\ H-4032 Debrecen, Böszörményi str.138.e-mail: zoltan_mezes@hotmail.co.uk
}

\begin{abstract}
Summary: Consideration of the soil and climatic conditions and their expected changes is very important in planning of new orchards. This research focuses on the expected climatic conditions and opportunities of sour cherry production in Central Hungary in the periods of 2021-2050 and 2071-2100, compared to the base period of 1961-1990. Results show that in the near future the expected changes are mostly favourable for sour cherry production, the utility values are increasing in most of the subregions. By the end of the century the utility values show further increase in the formerly colder subregions. However, in some subregions the utility values slightly decrease because of the appearance of the extreme dry and warm year types, though their values remain at the level of the base period or even higher.
\end{abstract}

Key words: fruit production, production area, climate change, sour cherry

\section{Introduction}

Hungary has a yearly sour cherry production of 60000 metric tonnes (figure 1.) this is the $4^{\text {th }}$ largest production in Europe and the $7^{\text {th }}$ in the world.

$1.8 \%$ of the area of Central Hungary is covered with fruit orchards which is the second biggest in the country. Sour cherry production is important in this region (chart 1 and 2) but the dispersion of the total production volume is big. First figure and chart clearly shows the serious effect of draught in 2002, spring frost hailstorms and summer draught in 2007 on the volume of production.

Yields are low all over Hungary often less than 3t/ha especially in Central Hungarian region. At least 15t/ha yield is needed for profitable sour cherry production according to Soltész (2004). There are lot of orchards over 25 years of age without professional plant protection, these plantations

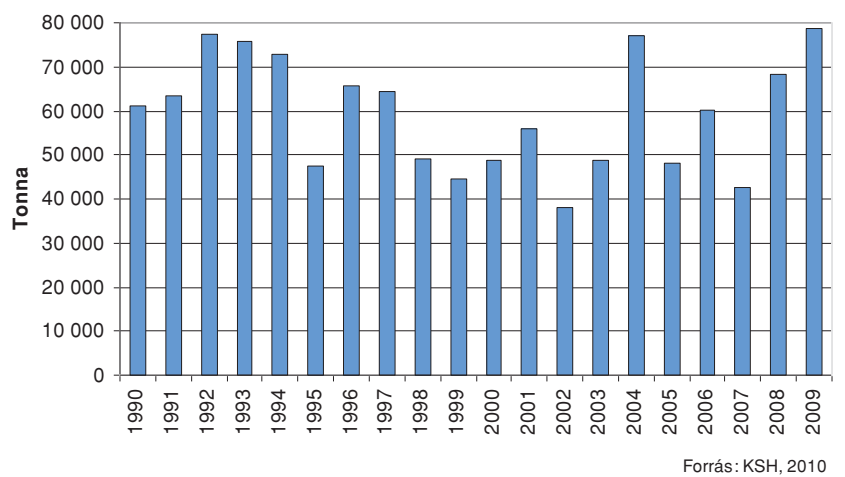

Figure 1. Quantity of sour cherry production (1990-2009)

effects the statistical yields badly because they have big spacing, less trees and low production compared to modern orchards. Due to deficient plant protection they suffer from

Chart 1. Sour cherry production of the different regions (metric tonnes) (source: KSH)

\begin{tabular}{|c|c|c|c|c|c|c|c|}
\hline & Central Hungary & $\begin{array}{c}\text { Central } \\
\text { Transdanubia } \\
\end{array}$ & $\begin{array}{c}\text { Western } \\
\text { Transdanubia } \\
\end{array}$ & $\begin{array}{c}\text { Southern } \\
\text { Transdanubia }\end{array}$ & North Hungary & $\begin{array}{c}\text { Northern Great } \\
\text { Plain }\end{array}$ & $\begin{array}{c}\text { Southern Great } \\
\text { Plain }\end{array}$ \\
\hline 2001 & 11360 & 6576 & 1092 & 4040 & 3510 & 24196 & 5242 \\
\hline 2002 & 3559 & 4585 & 942 & 1794 & 3318 & 19544 & 4408 \\
\hline 2003 & 4473 & 5596 & 1504 & 3459 & 4908 & 20324 & 8390 \\
\hline 2004 & 6273 & 6125 & 1783 & 4124 & 6315 & 22273 & 13260 \\
\hline 2005 & 4621 & 7391 & 1913 & 3371 & 6168 & 12862 & 11756 \\
\hline 2006 & 5880 & 8042 & 2417 & 3159 & 4859 & 15037 & 20783 \\
\hline 2007 & 5253 & 7099 & 2175 & 2414 & 2919 & 12344 & 10368 \\
\hline 2008 & 7112 & 9971 & 4262 & 3529 & 3728 & 23513 & 16040 \\
\hline 2009 & 9559 & 10323 & 6622 & 3966 & 6663 & 24249 & 17370 \\
\hline
\end{tabular}


Chart 2. Production area of Sour cherry in the different regions (hectares) (source: KSH)

\begin{tabular}{|l|c|c|c|c|c|c|c|}
\hline & Central Hungary & $\begin{array}{c}\text { Central } \\
\text { Transdanubia }\end{array}$ & $\begin{array}{c}\text { Western } \\
\text { Transdanubia }\end{array}$ & $\begin{array}{c}\text { Southern } \\
\text { Transdanubia }\end{array}$ & North Hungary & $\begin{array}{c}\text { Northern Great } \\
\text { Plain }\end{array}$ & $\begin{array}{c}\text { Southern Great } \\
\text { Plain }\end{array}$ \\
\hline $\mathbf{2 0 0 1}$ & 2567 & 1001 & 411 & 438 & 1352 & 4933 & 2592 \\
\hline $\mathbf{2 0 0 2}$ & 1818 & 815 & 185 & 445 & 1332 & 3620 & 2388 \\
\hline $\mathbf{2 0 0 3}$ & 2927 & 984 & 601 & 533 & 1992 & 6219 & 2674 \\
\hline $\mathbf{2 0 0 4}$ & 2700 & 1190 & 592 & 628 & 1973 & 6184 & 2669 \\
\hline $\mathbf{2 0 0 5}$ & 2904 & 1160 & 600 & 604 & 1985 & 6670 & 2796 \\
\hline $\mathbf{2 0 0 6}$ & 2169 & 1025 & 501 & 505 & 1435 & 5037 & 2328 \\
\hline $\mathbf{2 0 0 7}$ & 2191 & 1107 & 579 & 572 & 1457 & 5098 & 2405 \\
\hline
\end{tabular}

pests (fruit fly) and diseases (monilia) therefore the fruit quality is low, often more than $50 \%$ of the fruits are sold for juice factories or fermentation industry at very low price level. Growing potential of a region has to be evaluated for profitable production of an existing orchard or before planting a new one. Results for Central Hungary region are shown in this paper.

\section{Materials and methods}

Soil type evaluation is based on AGROTOPO data base made by MTA TAKI (Várallyai et al., 1979; Várallyai et.al., 1980). RegCM3 climate model (10 km grid resolution) by ELTE Meteorological Department is used for climate analysis (Torma et al., 2008, 2011). A1B future climate change scenario is valid for period 2021-2050 and 2071-2100, selected base period is 1961-1990. Based on the climate requirements of sour cherry different model years are made of the precipitation (April, May, June) and temperature (Tmin January-February, Tmin March-April). Twelve model categories are made plus one for the mixed type years. The research focuses on the hazards of production the biggest are the late winter (during external dormancy phase) and spring frosts (during flowering stage). A late winter frost during January-February has an effect on flower buds while spring frosts during March-April are hazardous for flowers and young fruits. Frost hardiness of flower buds and flowers are different so the frequency of critical temperature occurrence is monitored separately. Utility level calculation is based on frost frequency from the meteorological database. Frost free year has a utility value of 1 while each frost lower than the critical temperature reduces the utility level. Article of Szenteleki et al. (2011) contains the definition of the different model years.

Data analysis is made based on subregions. Usually one subregion contains more grid points but due to data handling practice only one is chosen for each subregion. We plan to use more grid points or use the average of grid points in each subregion. We made deep statistical analysis for Érd subregion - which has an important role in sour cherry production. Two sample tests (F-test for deviation, $t$ or Welch tests for expected values) are made to measure if the climate change parameters are significant compared to 1961-1990 base period.

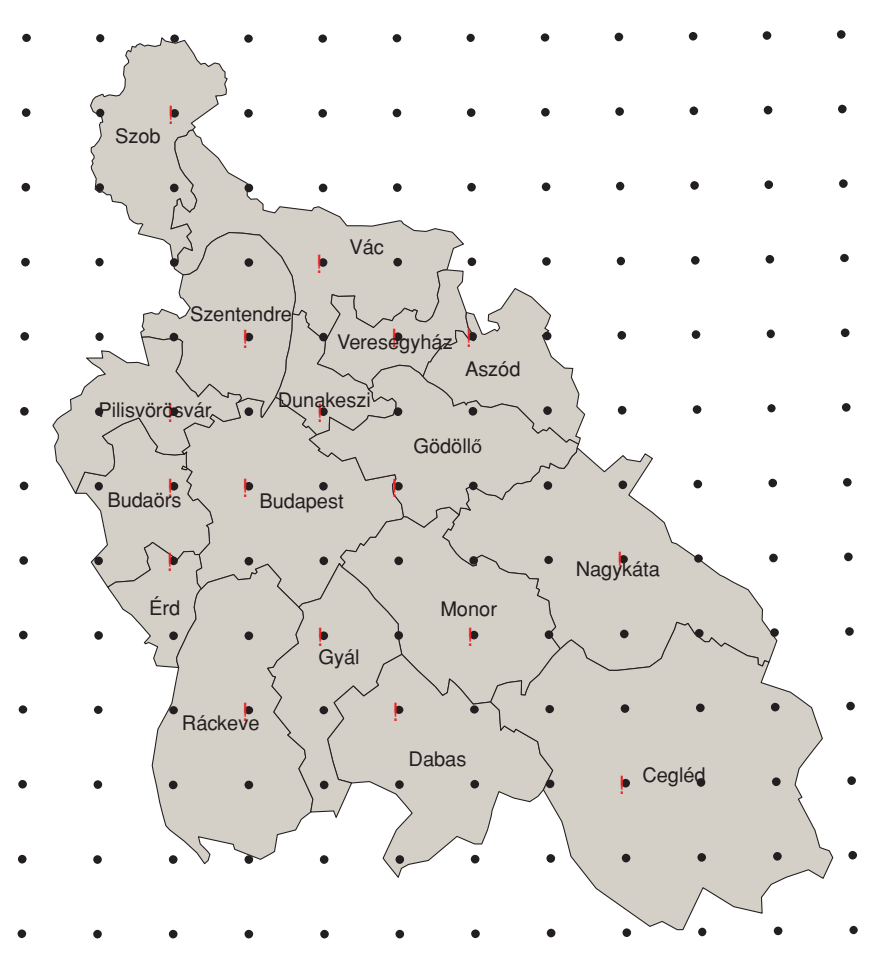

Figure 2. Subregions in Central Hungary and the grid of the RegCM model (highlighted grid points were analysed)

Primary data processing is made with our developed software FUIT-MET (Szenteleki et al., 2010, 2011), statistical tests are made with MS Excel and ArGIS 9.2 is used for map analysis. It is hard to get reliable data of the sour cherry production in subregion resolution. Only KSH has official data based on the grape and fruit orchard survey 2001 (Szögyü, 2001). After that no official survey made which covers the whole country.

\section{Results}

\section{Production area and soil research}

According to KSH survey made in 2001 sour cherry production proportion compared to the size of the subregion is $1,5 \%$ in Budaörs, $0,8-0,8 \%$ in Érd and Cegléd subregions. Compared to the total area of orchards in a subregion Gyál has $44 \%$, Cegléd has $34 \%$ and Budaörs has 33\% sour cherry 
Table 3. Areas (ha) of the different soil types, fruit growing and sour cherry production in the subregions

\begin{tabular}{|c|c|c|c|c|c|c|c|c|}
\hline Subregion & \multicolumn{6}{|c|}{ Soil types based on their utility values } & Fruit orchard (ha) & $\begin{array}{l}\text { Sour Cherry } \\
\text { orchard (ha) }\end{array}$ \\
\hline & H 1,1 & H 1 & Н 0,95 & Н 0,9 & Н 0,8 & H 0 & \multicolumn{2}{|c|}{2001} \\
\hline Aszódi & 7520,3 & 9021,4 & 0,0 & 935,3 & 3050,9 & 3375,8 & 172,9 & 12,2 \\
\hline Budaörsi & 6041,6 & 12021,5 & 0,0 & 0,0 & 248,8 & 5569,4 & 1051,4 & 350,4 \\
\hline Budapesti & 0,0 & 7557,8 & 0,0 & 5129,4 & 1305,8 & 38739,4 & 235,9 & 22,2 \\
\hline Ceglédi & 49362,6 & 200,0 & 0,0 & 38205,8 & 18231,9 & 17967,0 & 2754,7 & 946,5 \\
\hline Dabasi & 0,0 & 11341,5 & 0,0 & 9798,6 & 5229,1 & 22986,1 & 317,4 & 98,9 \\
\hline Dunakeszi & 0,0 & 6070,8 & 0,0 & 3423,0 & 782,8 & 1999,9 & 295,5 & 55,1 \\
\hline Érdi & 7775,9 & 3079,8 & 0,0 & 0,0 & 0,0 & 1026,6 & 393,6 & 92,5 \\
\hline Gödöllői & 6547,2 & 31364,8 & 0,0 & 728,4 & 138,1 & 194,0 & 128,6 & 4,2 \\
\hline Gyáli & 7,0 & 2820,3 & 0,0 & 9587,6 & 4519,9 & 12538,1 & 195,2 & 86,8 \\
\hline Monori & 13006,0 & 9999,0 & 0,0 & 10498,8 & 10433,7 & 826,3 & 593,8 & 155,0 \\
\hline Pilisvörösvári & 3751,9 & 14516,4 & 678,7 & 0,0 & 0,0 & 6002,7 & 444,0 & 53,5 \\
\hline Ráckevei & 21288,8 & 66,0 & 0,0 & 6446,7 & 775,4 & 33494,8 & 1157,7 & 283,0 \\
\hline Szentendrei & 0,0 & 8154,7 & 11084,7 & 755,4 & 223,6 & 12261,2 & 441,8 & 36,5 \\
\hline Szobi & 0,0 & 10578,2 & 19064,5 & 0,0 & 0,0 & 1880,4 & 1095,7 & 108,8 \\
\hline Váci & 0,8 & 17258,4 & 17550,7 & 2102,4 & 1375,2 & 4944,8 & 788,9 & 177,6 \\
\hline Veresegyházi & 0,0 & 14195,9 & 0,0 & 267,6 & 906,1 & 515,3 & 328,9 & 73,8 \\
\hline
\end{tabular}

plantation. (According to data from 2001 Törökbálint had an important role in sour cherry production of Budaörs subregion but today those orchards are over.)

Soil types of the region with utility rates (based on Szenteleki et al., 2011) are shown on figure 3. Red spots show the settlements with sour cherry production according to KSH database.

Chernozem are the best soils for sour cherry production, they are able to partly protect against negative climate effect such as draught. Érd (65\%), Nagykáta (49\%) and Cegléd subregion has the biggest proportion of chernozem soils ( $3^{\text {rd }}$ chart). Most of the production areas have brown soils which are good for sour cherry but some orchards stand on bad soil types for instance in Ráckeve and Dabas subregions. Different utilization is suggested in these regions than sour cherry production.

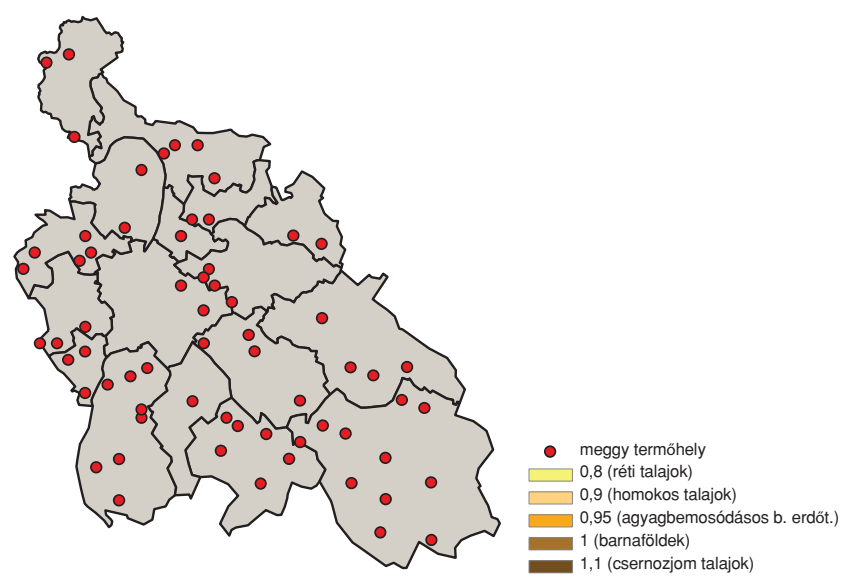

Figure 3. Soil types in Central Hungary and the sour cherry production sites

\section{Climate conditions}

Calculation of utility values is based on the effect of different climate events on sour cherry production. Therefore if spring frosts frequently occur in a subregion, then the utility value is lower. We made groups of the model years according to precipitation and temperature data. Each model years has a utility value based on the ecological requirements of sour cherry. Article of SZENTELEKI et al. (2011) contains the definition of the different model years, hereby is a summary (Chart 4.).

Table 4. Climatic year types and their utility values in case of sour cherry production

\begin{tabular}{|l|c|}
\hline \multicolumn{1}{|c|}{ model year } & utility value (H) \\
\hline extreme dry and extreme cold & 0,2 \\
\hline extreme dry and cold & 0,4 \\
\hline extreme dry and hot & 0,5 \\
\hline dry and extreme cold & 0,2 \\
\hline dry and cold & 0,82 \\
\hline dry and hot & 0,86 \\
\hline wet and extreme cold & 0,35 \\
\hline wet and cold & 0,92 \\
\hline wet and hot & 1 \\
\hline extreme wet and extreme cold & 0,2 \\
\hline extreme wet and cold & 0,45 \\
\hline extreme wet and hot & 0,5 \\
\hline mixed year type (average) & 0,88 \\
\hline
\end{tabular}

The flower bud formation starts after harvest by the end of July lasts during August, therefore the yield of the actual year is always influenced by the rainfall of the previous 
summer. If the water supply of the soil is extremely low than the quantity of flower buds for next year can be less with even $20 \%$ than normal. The above mentioned values are based on 8 years database of the orchard situated in Pusztaszabolcs, Central Hungary region. If rainfall of the previous August is less than $5 \mathrm{~mm}$, than a $50 \%$ rate is used for the utility value of the actual year $\left(H^{*} 0,5=>H\right)$. If rainfall of the previous August is less than $20 \mathrm{~mm}$, than a $80 \%$ rate is used for the utility value of the actual year $\left(\mathrm{H}^{*} 0,8=>\mathrm{H}\right)$.

Thirty years time periods are calculated in the research (1961-1990, 2021-2050, 2071--2100). Each and every year grouped to a model year and the utility value calculation is made. The result shows that growing conditions are going to be better for sour cherry in the near future. Utility values are rising in every subregion (figure 4.). The reason why is that frequency of the cold years with low utility value is reducing, while the dry and hot years are more frequent in the future (figure 5.).

A key factor of sour cherry production is the spring frost. According to our research spring frost occurrence is reducing in the future. Sour cherry harvested during June July, so summer draught has less effect on the fruit. On the other hand size of the fruit is going to be smaller and harvest period earlier. Hungarian sour cherry production has a short season. It is necessary to prolong the harvest period with earlier varieties such as Piramis and Dukát. These varieties had good yield and fruit quality during 2008 in the experimental orchard in Érd. Ripening time of Dukát is at the end of May while Piramis ripens at the beginning of June. Both have a good taste comparable to Érdi bötermö. (Apostol, 2008.) Early varieties are good for fresh market, on the other hand canning industry requires late varieties to have optimal use of capacity during the whole season. Nowadays sour cherry season is short and due to the harvest peak market price is going down. Late ripening varieties (after Kántorjánosi and Újfehértói fürtös) such as Éva and Petri can be able to prolong the season and seems promising (Szabó, 2008).

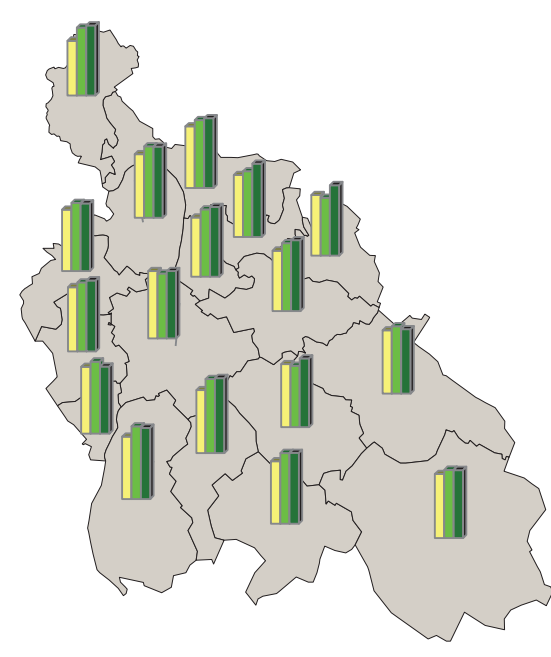

0,4

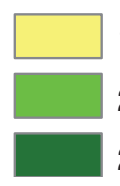

1961-1990

2021-2150

$2071-2100$

Figure 4. Changes of the climatic utility values (the value refers to the highest column in the chart symbol)

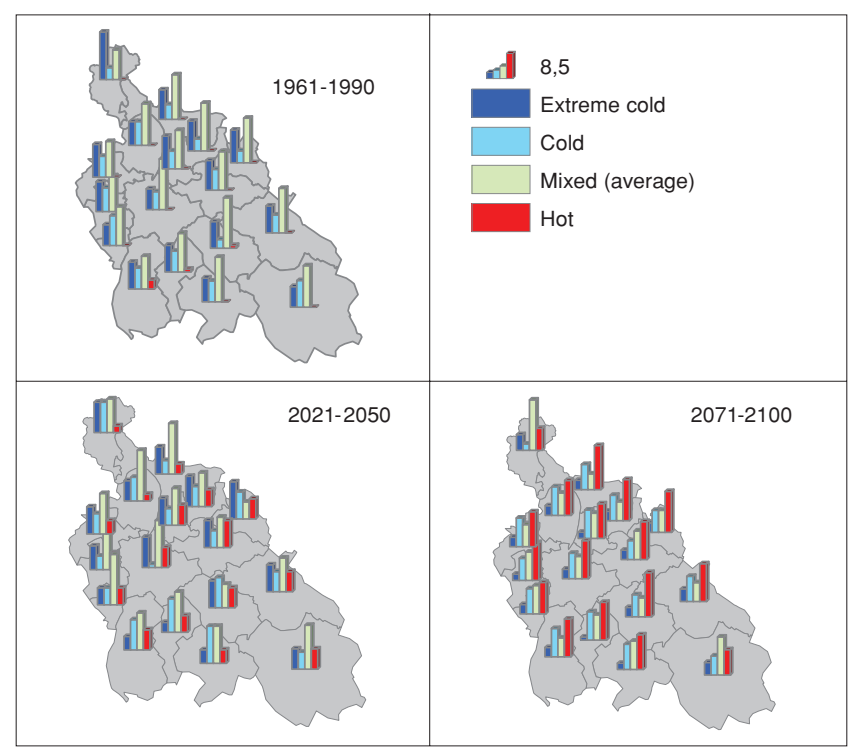

Figure 5. Changes of climatic year types regarding temperature

Utility levels are reducing by the end of the century in some subregions because extreme dry and hot, and extreme dry and cold model years occur. $6^{\text {th }}$ figure clearly shows that the number of extreme rainy model years is reducing while extreme dry model years are increasing. Therefore in new orchards producing for fresh market irrigation is recommended. Irrigation is good for industrial production as well but in the economical point of view it is not profitable. Price of industrial sour cherry has a big fluctuation (45-300 Ft/kg +VAT). The cost of production of the fruit without irrigation is approx. 90-120 Ft/kg +VAT. Market price has a 4-6 years cycle but the average price of the last five years is $130-150 \mathrm{Ft} / \mathrm{kg}+\mathrm{VAT}$ which is not enough to build irrigation. (Apáti, 2009.)

We made statistical test for Érd subregion to see if the utility value change in the future is significant. Results are shown in $5^{\text {th }}$ chart.

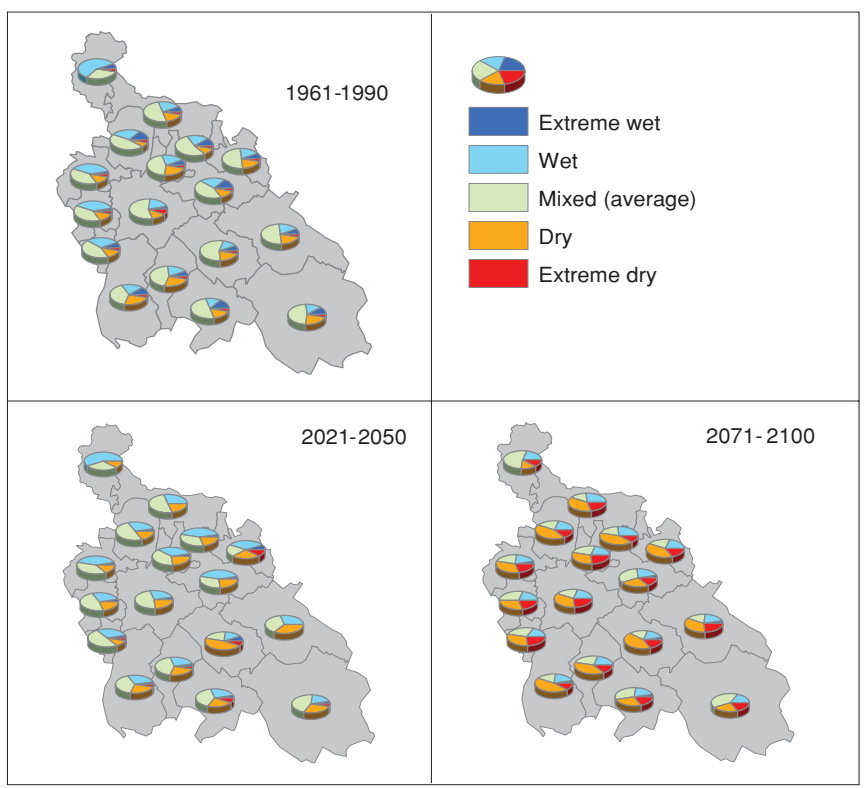

Figure 6. Changes of climatic year types regarding precipitation 
Table 5. Some climatic parameters in the Érd subregion (* means the significant difference compared to the base period of 1961-1990)

\begin{tabular}{|c|c|c|c|c|c|c|}
\hline & \multicolumn{2}{|c|}{ 1961-990 } & \multicolumn{2}{|c|}{ 2021-2050 } & \multicolumn{2}{|c|}{ 2071-2100 } \\
\hline & average & $\begin{array}{l}\text { standard } \\
\text { deviation }\end{array}$ & average & $\begin{array}{l}\text { standard } \\
\text { deviation }\end{array}$ & average & $\begin{array}{l}\text { standard } \\
\text { deviation }\end{array}$ \\
\hline average temperature $\left({ }^{\circ} \mathrm{C}\right)$ & 9,79 & 0,77 & $10,90^{*}$ & 0,72 & $12,84 *$ & 0,79 \\
\hline minimum temperature in $\operatorname{March}\left({ }^{\circ} \mathrm{C}\right)$ & 1,39 & 1,62 & $2,58 *$ & 1,79 & $4,03 *$ & 1,94 \\
\hline precipitation in June ( $\mathrm{mm}$ ) & 49,80 & 24,87 & 52,04 & $37,98 *$ & $30,97 *$ & 25,45 \\
\hline maximum temperature in June $\left({ }^{\circ} \mathrm{C}\right)$ & 23,81 & 1,97 & 24,75 & 2,49 & $27,50 *$ & 2,31 \\
\hline
\end{tabular}

Sour cherry needs 500-600 mm average yearly rainfall according to the literature (Pór and Fabula, 1982). Average precipitation is reducing in the future but it will be enough to fulfil the requirements of sour cherry. Choosing the right rootstock is going to be an issue. There is significant rootstock breeding activity nowadays which can help growers to find the right variety in new plantations (Bujdosó G., 2004; Bujdosó G. - Hrotkó K., 2005).

Average temperature is rising in the future. Ecological requirement of sour cherry is 8-10 C (Mohácsy and Maliga, 1956) but average temperatures will be higher by the end of the century. Flowering period nowadays starts at end of March but dormancy phase is going to be shorter due to higher winter and spring temperatures which has an effect on the flowering as well. Period is going to be shorter and starts earlier in the future. Examination made on minimum temperatures shows that there will be frosts during March, but frequency of the spring frosts is significantly reducing. During 1961-1990 there was 23 years with less then -3 C spring frost during March, during 2021-2050 this value is going to be 14, while during 2071-2100 there will be only 10 years with such frost. During April most probably there won't be lower temperatures than -1,5 $\mathrm{C}$ in the future (Ladányi et al., 2010). However the above results shows better flowering periods in the future with less frost damage more research has to be done to prove the statement.

Precipitation during May and June has an important role in fruit growing. Average rainfall in May will not change significantly during 2021-2050, but reducing a bit by the end of the century. Slight reduction of rainfall itself has no big effect on fruit quality but together with warming will effect badly the production (Beczner, 2011). On the other hand precipitation in June has a significant reduction in the future. There was only 2 years during the base period in this category but in 2021-2050 this number increases to 7, and in $2071-2100$ to 12 which means that every $3^{\text {rd }}$ year is going to be extreme dry by the end of the century.

According to Bujdosó (2006) 20-26 C temperature is necessary during ripening for optimal enzyme activity. If the temperature is higher than ripening fail happens which has a negative effect on fruit quality and taste. Perhaps it can cause problems by the end of the century because of the high maximum temperatures during June.

Detailed analysis proves the utility values shown on figure 4. in Érd subregion. During 2021-2050 utility values increasing compared to the base period but they will be reduced to the original value by the end of the century.

\section{Acknowledgement}

Research was sponsored by TECH_08-A3/2-2008-0373 and TECH_08-A4/2-2008-0138 grants.

\section{References}

Apáti, F. (2009): A meggytermesztés jelene és kilátásai a gazdaságosság tükrében. Agrofórum, 5: 70-73.

Apostol, J. (2008): Érdi Gyümölcs- és Dísznövény Termesztési Kutató Fejlesztő Kht. 2008.07.11-i előadás

Beczner, J. (2011): A meggy élelmiszer-biztonsági kockázata. „KLÍMA-21” Füzetek, 64: 162-172.

Bujdosó, G. (2004): Gondoljuk át a növekedést mérséklő alanyok használatát!, Gyakorlati Agrofórum, 15. (2): 43-45.

Bujdosó, G. (2006): Cseresznye- és meggytermesztés intenzitásának növelése növekedést szabályozó alanyokkal. Doktori $(\mathrm{PhD})$ értekezés, BCE

Bujdosó, G., Hrotkó, K. (2005): Alany-nemes kölcsönhatások vizsgálata növekedést mérséklő alanyokra szemzett cseresznyeés meggyfajtáknál., „Lippay János - Ormos Imre - Vas Károly” Tudományos Ülésszak, Összefoglalók, Kertészettudomány, p.192.

Ladányi, M., Persely, Sz., Szabó, T., Szabó, Z., Soltész, M. \& Nyéki J. (2010): Climatic indicator analysis of blooming time for sour cherries. International Journal of Horticultural Science, 16. (1): 11-16.

Mohácsy, M., Maliga, P. (1956): Cseresznye- és meggytermesztés. Mezőgazdasági Kiadó, Budapest

Nyujtó F. (1971): A cseresznye és meggy alanyhatás kísérletek részeredményei. GYDKI kiadvány, 6: 89-107.

Pór, J., Faluba, Z. (1982): Cseresznye és meggy. Mezőgazdasági Kiadó, Budapest

Soltész, M. (2004): Meggy. [In: Papp, J. (2004): A gyümölcsök termesztése.] Mezőgazda Kiadó, Budapest.

Szabó, T. (2008): Az északkelet-magyarországi meggy tájfajta szelekció eredményei és gazdasági jelentősége, Doktori $(\mathrm{PhD})$ értekezés, BCE.

Szenteleki, K., Bartholy, J., Mézes, Z., Soltész, M. \& Torma, Cs. (2010): Klímakockázati adatbázisok a gyümölcstermesztésben. [In: Herdon M., Kapronczai I. (szerk): Agrárinformatikai tanulmányok I.], http://tamop.magisz.org/poldoc/docstore/tanulmany/AT-I.pdf 
Szenteleki, K., Mézes, Z., Nyéki, J., Szabó, Z., Gaál, M. \& Soltész, M. (2011): Meggy termékpályák meghatározó elemei., „KLÍMA-21” Füzetek, 64: 78-91.

Torma, Cs., Bartholy, J., Pongracz, R., Barcza, Z., Coppola, E. \& Giorgi, F. (2008): Adaptation and validation of the RegCM3 climate model for the Carpathian Basin. Időjárás, 112. (3-4): 233-247.

Torma, Cs., Coppola, E., Giorgi, F., Bartholy, J. \& Pongrácz,

R. (2011): Validation of a high resolution version of the regional climate model RegCM3 over the Carpathian Basin., Journal of Hydrometeorology, 12: 84-100.

Várallyay, Gy., Szűcs, K., Murányi, A., Rajkai, K., Zilahy, P. (1979): Magyarország termőhelyi adottságait meghatározó talajtani tényezők 1:100 000 méretarányú térképe I., Talajtan és Agrokémia, 28: 363-384.

Várallyay, Gy., Szücs, K., Murányi, A., Rajkai, K., Zilahy, P. (1980): Magyarország termőhelyi adottságait meghatározó talajtani tényezők 1:100 000 méretarányú térképe II., Talajtan és Agrokémia, 29: 35-76. 